var, vises man ud til det derude, der er i frydefuld forandring. Ikke med lalleglad modernitetsåbenhed, men med ståsted på den troens grund, der lader os se menneskelivet som skabt, som noget, Gud har store planer med.

Vekselvirkning hedder det. Og det er noget helt, helt andet end den fastfrosne stillingskrig mellem nationalisme-fikserede modstandere, der ikke har noget at lade hinanden høre, hvad overfladisk grundtvigforståelse angår, og som - hvad værre er - har overladt højskolen til valget mellem enten i forlegen afmagt at vende ryggen til eller ublufærdigt at hengive sig til, om end ikke det første og bedste, så dog det sidste og værste.

Så det er mit bud i dag: Ned i maskinrummet. Gør jer den anstrengelse at se, hvad der sker. Dyrk synerne og søg nye horisonter. Alt andet end gamle holdepunkter eller lette løsninger.

\title{
Noter
}

Citeret fra Birgitte Drud Nielsen 2002/12,3 (forstander på Den Skandinaviske Designhøjskole).

\section{Grundtvig og folkehøjskolen i dag: Grundtvig og "Grundtvig" anno 2004}

\section{Af Jes Fabricius Møller}

Grundtvig er ikke længere det ideologiske grundlag for højskolerne, har det lydt i pressen i januar måned 2004. Oure Idrætshøjskole fastslår uden omsvøb:

Det bemærkelsesværdige ved Grundtvig var, at han koblede nationalromantikken og aggressiv modstand mod hele oplysningsprojektet med en bibelfundamentalistisk opfattelse af historien og mennesket.

Det er vanskeligt at blive mere upræcis inden for hæderlighedens rammer, men lad det nu ligge. Det væsentlige her er standpunktets klarhed, der er udbredt i de danske højskoler. Det kan man se af fælleskataloget årgang 2004 for landets 86 højskoler.

Flere og flere skoler profilerer sig på færdighedskurser og kompetencegivende undervisning på bekostning af klassiske højskoleværdier som folkelig oplysning eller åndelig dannelse. "Vi 
danner din succes" er fælleskatalogets motto. Det handler jo stadig lidt om dannelse, men kodeordet er succes, et ord, der for blot få år siden ville have været bandlyst fra højskoleverdenen. Det smagte for meget af Thatcher-firsernes egoisme og for lidt af fællesskabets forpligtelse. Askov Højskole tager skridtet fuldt ud og skriver direkte: "Kompetencen - den får du på Askov."

Det forbavsende er i første omgang, at offentligheden betragter det som en nyhed, at Grundtvig er ude af cirkulation. Det har han på mange måder været næsten siden krigen. Da besættelsestidens nationale vækkelse var klinget ud - og det gik meget hurtigt - stod der Dostojevski, Kierkegaard eller Løgstrup på læseplanerne, ikke mindst på Askov. Grundtvigs navn blev de fleste steder kun nævnt i festtalerne.

Oure Idrætshøjskole er blot en af mange højskoler, der i årevis har været $\mathrm{i}$ åbenlys konflikt med det grundtvigske oplysningsideal. Den er i åndelig forstand en aflægger af Den røde Højskole i Svendborg, der i masser af år var, hvad man dengang kaldte en kommunistrede. I det selskab var Grundtvig ikke inde i varmen.

Bortset fra det må det ikke komme som nogen overraskelse, at Grundtvig er forældet. Selvfølgelig er han da det. Man kan ikke som engageret borger i samfundstilstanden 2004 banke på Grundtvigs dør anno 18xx og spørge: "Hva' så Nikkelaj? Hvor ska' vi hen, du?" Selvfølgelig har Grundtvig som forfatter ikke noget direkte bud på det. Han taler kun til os gennem traditionens stadig tykkere slør, som gør det stadig vanskeligere at nå ind til "den ægte Grundtvig".

Det kan illustreres meget godt med den måde, Grundtvigs betydning beskrives. Han er blevet sammenlignet med en vandåre eller et oliefyr i dagens Danmark, det vil sige, at han udfylder en vital men usynlig funktion. Ingen steder træder han frem i første række.

Siger man "Grundtvig" i dag, mener man som oftest ikke N. F. S. Grundtvig himself. Hans navn bruges som samlebetegnelse for det, vi i almindelighed som danskere er blevet til eller lever i. Det er, hvad Ove Korsgaard og Kim Arne Pedersen. hver især har kaldt "myten Grundtvig". Navnet "Grnndtvig" anvendes som retorisk figur, en såkaldt metonymi, det vil sige et billede på helheden. Omtrent på samme måde som man siger "Slotsholmen" og mener centraladministrationen som helhed. Med "Grundtvig" er så meget sagt, uden at det egentlig siges.

Der er fra begyndelsen en kløft mellem Grundtvig og grundtvigianernes "Grundtvig". ${ }^{1}$ Meget er blevet gjort for at skille den ægte N. F. S. Grundtvig ud fra de varierende fortolkninger. Konstant søges svar på spørgsmålet "Hvad mente Grundtvig egentlig?" i håbet om, at svaret på så meget andet end netop det følger med. Det er i vid udstrækning et forgæves håb. "Det har været Grundtvigs skæbne at 
blive overskygget af den [...] bevægelse, der med større eller mindre ret kaldes ved hans navn," som P. G. Lindhardt skrev til indledning i sin lille bog om Grundtvig. Grundtvig var opmærksom på problemet og forsøgte selv at lægge afstand til grundtvigianismen i det bekendte udbrud fra 1847:

hvad de saakaldte 'Grundtvigianere' kan have gjort, vedkommer mig saameget mindre, som de er mig aldeles ubekiendte. Til at stifte Partier har jeg nemlig aldrig duet, men jeg har heller aldrig prøvet derpaa, [...] og vilde man derfor, som jeg, giøre sig den Umage, at see lidt nærmere til, da skulde man snart finde, at af de saakaldte 'Grundtvigianere' vil den ene rose min Prædiken eller Kirkesang, men laste min Mythologiskhed, Historiskhed og Pæredanskhed, eller dog i det mindste min Blindhed for de gudelige Forsamlinger og Missionsselskabernes Ypperlighed, medens den anden vil giøre omvendt, saa at, om jeg ogsaa havde to halve Partier, blev der dog aldrig et heelt af dem.

Grundtvigs fraskrivelse af fadderskabet var forgæves. Han er siden blevet taget til indtægt for mangt og meget og ofte også modsatrettede synspunkter. Det kan hænge sammen med, at han var modsætningsfyldt selv. Hans liv var fyldt med årstal, der skiller et "før" fra et "efter". Senest har K. E. Bugge udgivet en fremragende lille bog, der viser 1839 som det år, da Grundtvig ændrede kurs omtrent 180 grader i spørgsmålet om slavernes befrielse på de dansk-vestindiske øer. I 1838 var han nogenledes forbeholden, mens han i det næunte år gik helhjertet ind i en komité, der arbejdede for slaveriet afskaffelse.

"Grundtvigs betydelse för den danska idéhistorien i allmänhet och den politiska i synnerhet kan inte överskattas," skriver lektor i idéhistorie Ola Fransson. ${ }^{3}$ Det er måske netop, hvad den kan. Går man ind og ser konkret på den rolle, som Grundtvig spillede i sin samtid, var den mindre end de fleste antager. Anders Pontoppidan Thyssens disputats, Den ny-grundtvigske bevagelse, fra 1957 gennemgår til indledning Grundtvigs rolle i de sektorer, der knyttedes til hans navn, kirken, skolen, det politiske og de folkelige bevægelser, og Thyssen nedtoner systematisk Grundtvigs praktiske betydning til fordel for ikke mindst Kold. Grundtvig var i Thyssens optik snarere en randfigur i grundtvigianismen. Først i 1860'erne blev hans person centrum for det, der netop i disse år med nogen ret kunne kaldes den grundtvigske bevægelse, bestemt form ental. Både tidligere og især senere efter Grundtvigs død var bevægelsen så splittet, at det er vanskeligt at tale om en enhed.

P. G. Lindhardt forlængede i en kronik-anmeldelse i JyllandsPosten i forbindelse med disputatsforsvaret Thyssens pointe ved at 
erklære grundtvigianismen for død. Han daterede den ulykkelige begivenhed til århundredskiftet og remsede hurtigt nederlaget op i politisk, folkelig, pædagogisk og kirkelig henseende:

Selvom grundtvigianismen fik afgørende indflydelse på dannelsen af vore to venstrepartiers ideologi, blev den ikke selv af videre politisk betydning; dens folkelige kultur og de dermed sammenhængende skoletanker led katastrofalt nederlag overfor examensskolen, det kirkelige frihedssyn har inspireret vor kirkelige lovgivning, men langtfra sejret; den 'kirkelige anskuelse' er selv blandt grundtvigianere nu om dage en ren musæumsgenstand osv. osv.

Hal Kochs tilsvarende kronik - i Politiken naturligvis - hed ganske enkelt "Grundtvigsk nederlag".

Der er ingen tvivl om, at tillægsordet "grundtvigsk" ikke længere betegner et retningspræg. Det har ikke længere forne tiders radikalitet over sig. At være "grundtvigsk" betyder snarere, at man helst ikke vil træde nogen over tæerne. Det er tydeligst i forbindelse med bispevalgene, hvor de klassiske retningspræg er på vej ud. Grundtvig blev titulær biskop i $1861 .{ }^{4}$ Hvis tendensen fra det seneste bispevalg $\mathrm{i}$ Ribe fortsætter, vil det ende med, at alle biskopper er titulære grundtvigianere.

Hvad der er tilbage af Grundtvigs synspunkter i vore dages samfund er efterhånden så udvandet, at det har homøopatisk karakter. Alligevel nægter "Grundtvig" til trods for stadige erklæringer om grundtvigianismens død at forsvinde fra vores kulturelle selvbillede. Nogle vil sige, at han spøger, mens andre som nævnt vil udnævne ham til dansk kulturs varmemester eller vandforsyning. Personligt har jeg ikke noget imod tabet af radikalitet til fordel for besindelsen og det vennesæle forsøg på at være lidt rummelig.

Meget få mennesker er blevet grundtvigianere af at læse Grundtvig. De fleste er blevet det ved at have mødt levende mennesker, der virker og arbejder i deres tid. Derfor er grundtvigianismen egentlig så udogmatisk en bevægelse - usammenhængende, ufokuseret, vil kritikerne sige. Den blev en bevægelse, der i mangfoldige former var med til at danne det moderne Danmark uden i nogen stærk grad at have følt en forpligtelse over for den bogstavelige udlægning af Grundtvigs skrifter. Højskolebevægelsen, for eksempel, begyndte med bønderkarle, der skulle lære om nordisk mytologi og spat hos heste. I den anden ende af den historiske proces finder man Ubberup Højskoles kurser for overvægtige og sportskurserne i Oure. Her kommer hestene måske ind $\mathrm{i}$ billedet igen, men unægtelig $\mathrm{i}$ en anden sammenhæng, og det er netop pointen: at vedkende sig den historiske forandrings vilkår. 
Man læser ikke Grundtvig, fordi hans budskab er gyldigt, men fordi han har gjort sig gældende. Grundtvigs værk er uhyre spændende og vidtstrakt. Men pas på! Man har - som det er blevet sagt - fundet forskere derinde. Man læser Grundtvig, fordi han satte sit mærke på det danske samfund. Man læser Grundtvig som en historisk forudsætning for nutiden. Selvfølgelig var han nationalist. Herregud, det var de jo alle sammen. I den læsning hænder det, at man ser glimt af guldet, at teksten pludselig taler direkte til en, men det er en sidegevinst. Grundtvig har samme betydning for dagens Danmark, som Marx har for nutidens socialdemokrater. Ingen af dem er marxister i nogen meningsfuld betydning af ordet, men hvem kunne finde på at forklare Socialdemokratiet uden at nævne Marx?

\section{Noter}

1 Se Johansen 1950.

$2 \quad D K T$, nr. 117, 17. okt. 1847. Det var et svar på et anonymt indlæg i Berlingske Tidende 5/10 1847, ifølge hvilket "Grundtvigianerne sammenblande efter deres Mesters Eksempel, Danskhed, Nordiskhed og Skandinavisme med Christendom, drive ofte et Væsen med det Folkelige og Nationale, som overført paa et helligt Gebeet seer meget betænkeligt ud." Cit. efter Grundtvig sst.

3 "I skuggan av Grundtvig" i Sanders 2003, 126

4 Dette er, som Skat Arildsen viste i Kirken og Tiden (1935), faktisk en tilsnigelse, idet han teknisk set ikke fik titel, men kun rang af biskop.

\section{Grundtvig og folkehøjskolen i dag: "Nyt Syn på Grundtvig" og den grundtvigske højskoletanke}

Skitse til et nutidigt højskolesyn i perspektiv af den aktuelle debat $i$ offentlighed og forskning.

\section{Af Kim Arne Pedersen}

I begyndelsen af januar 2004 (5.1.2004) blev et interview med undertegnede i Kristeligt Dagblad startskuddet til en kort, hektisk og sensationspræget højskoledebat - en debat, der i en lidt anden aftapning blussede op igen i forbindelse med reaktionerne på folkehøjskolernes nye slogan: "Vi danner din succes" i foråret 2004. Baggrunden for den første debatbølge var det pågældende interviews 